\section{First mammal-like reptile from Australia}

THE first mammal-like reptile fossil to be found in Australia, from the Arcadia Formation of south-east Queensland, was recently described by Thulborn ${ }^{1}$. The specimen in question is a partial left quadrate whose morphology matches a suite of characters which Thulborn feels appear "to be unique to dicynodonts", following Watson's ${ }^{2}$ description. Furthermore, Thulborn states that the specimen, Queensland Museum F12178, finds its closest match in the dicynodont $\mathrm{Kan}$ nemeyeria, being virtually identical to one example illustrated by Watson ${ }^{2}$. He therefore concludes that the quadrate belonged to a dicynodont closely related to (or perhaps identical with) Kannemeyeria.

This is an important conclusion because it is implicated in the dating of the Arcadia Formation which various evidence ${ }^{1}$ points to being correlated with the Lystrosaurus Zone of South Africa. However, Kannemeyeria is usually thought to be associated with Cynognathus Zone (Lower Triassic) deposits, not with those of the earlier Lystrosaurus Zone. If the new fossil is indeed Kannemeyeria then either it is a very early occurrence of this genus, in the Arcadia Formation, or the Arcadia is not correlated with the South African Lystrosaurus Zone, despite the evidence to the contrary. Even if the fossil is only closely related to Kannemeyeria, not actually a member of that genus, this is still a surprising conclusion, as no known relatives of Kannemeyeria are found in deposits earlier than those of the Cynognathus Zone ${ }^{3}$.

However, there is little evidence to support the contention that the new specimen is Kannemeyeria or a similar genus, because the dicynodontian quadrate has no features of diagnostic significance (except perhaps in two advanced Triassic forms ${ }^{4}$ ). Although Queensland Museum F12178 is undoubtedly dicynodontian (sensu Cluver and $\mathrm{King}^{5}$ ), and although it and Kannemeyeria do appear similar, Queensland Museum F12178 also bears similarities to Lystrosaurus ${ }^{6}$, Dicynodon ${ }^{7}$, or indeed to almost any other dicynodontian. The problems of dating mentioned above may be solved by assuming that QM 12178 is not Kannemeyeria, or a close relative, but is in fact Lystrosaurus, the common fossil of the Lystrosaurus Zone.

Thulborn also mentions that Kannemeyeria and Lystrosaurus might have been contemporaneous in the Puesto Viejo Formation of Argentina, probably the earliest occurrence of Kannemeyeria. This is not a widely held view and has no fossil evidence to substantiate it, but it is in any case contradictory to Thulborn's suggestion that the Arcadia is not necessarily correlated with the South African Lystrosaurus Zone. If Kannemeyeria and Lystrosaurus did coexist, there is nothing to prevent the Arcadia being correlated with the Lystrosaurus Zone. The Puesto Viejo cannot be used to illustrate this, however, as it is almost certainly of Cynognathus Zone age ${ }^{8}$.

In conclusion, it would seem simpler to regard the quadrate QMF12178 as belonging to a specimen of Lystrosaurus, and the Arcadia Formation as Lystrosaurus Zone age. This would be consistent with the evidence from associated remains and palynology mentioned by Thulborn.

The Zoological Collections,

$$
\text { G. M. KING }
$$

University Museum,

Parks Road,

Oxford OX $13 P W$, UK

1. Thulborn, R. A Nature 303, 330-331 (1983)

Watson, D. M. S. Proc. zool. Soc. Lond. 118, 823-877 (1948)

3. Anderson, J. M. \& Cruickshank, A. R. I. Palaeont. afr. 21, 15-44 (1978)

4. Keyser, A. W. Palaeont. afr. 17, 57-68 (1974).

5. Cluver, M. A. \& King, G. M. Ann. S. Afr. Mus. 91, 195-273 (1983).

6. Cluver, M. A. Ann. S. Afr. Mus. 56, 155-274 (1971).

7. King, G. M. Phil. Trans. R. Soc. B291, 243-322 (1981).

8. Bonaparte, J. F. Proc. 2nd Gondwana Symp., South Africa, 665-682 (C.S.I.R., Pretoria, 1970).

THULBORN REPLIES-King states that no known relatives of Kannemeyeria are found in deposits older than those of the Cynognathus Zone. However, Bonaparte reported ${ }^{1}$ parts of several kannemeyeriid skulls, along with remains of a proterosuchid thecodontian, from the basal part of the Puesto Viejo Formation, Argentina. Radiometric dating confirmed that the fossiliferous beds were probably equivalent in age to the South African Lystrosaurus Zone.

To some extent dicynodont genera can be distinguished through differences in quadrate morphology-in the relative shapes and proportions of the condyles, in the degree of closure of the quadrate foramen and (in some cases) in the development of an antero-medial wing against the pterygoid. I compared the Arcadia specimen first-hand with the quadrates of various dicynodonts, including Kannemeyeria and African and Antarctic specimens of Lystrosaurus. In its size, and in its gross and detailed morphology, the Arcadia specimen found its closest match in the Kannemeyeria quadrate illustrated by Watson ${ }^{2}$; by contrast, it bears only a general resemblance to the quadrate of Lystrosaurus (see, for example, those specimens figured by Cluver $^{3}$ ).

While the Arcadia quadrate is definitely identifiable as that of a dicynodont, it does not show sufficient detail to warrant its assignment to any new or existing genus, be it Kannemeyeria or Lystrosaurus. It seems very likely that the Arcadia fauna is equivalent in age to that of the South African Lystrosaurus Zone $e^{4-6}$, but this fact cannot be used to argue that any dicynodont fragment found in the Arcadia Formation must inevitably represent the genus Lystrosaurus.

\footnotetext{
1. Bonaparte, J. F. Anais II Congr. Latino-Americano Paleont., Porto Alegre, Vol. 1, 277-288 (1981).

2. Watson, D. M. S. Proc. zool. Soc. Lond. 118, 823-877 (1948).

3. Cluver, M. A. Ann. S. Afr. Mus. 56, 155-274 (1971).

4. Foster, C. B. Publs geol. Surv. Qd 372, 1-244 (1979).

5. Thulborn, R. A. Mem. Qd Mus. 19, 331-355 (1979).

6. Warren, A. Alcheringa 4, 25-36 (1980)
}

RICHARD A. THULBORN

Department of Zoology,

University of Queensland,

St Lucia,

Queensland 4067, Australia

\section{Correlation of Tulu Bor Tuff at Koobi Fora with the Sidi Hakoma Tuff at Hadar}

BROWN $^{1}$ correlates the Sidi Hakoma Tuff (SHT) of Hadar with the Tulu Bor Tuff of East Turkana using chemical fingerprinting, and concludes that our $\mathrm{K} / \mathrm{Ar}$ $\mathrm{age}^{2}$ for the variably altered Kada Moumou Basalt (KMB), interpreted to be stratigraphically above SHT, is too old by $\sim 0.5 \mathrm{Myr}$. This conclusion is hasty.

(1) Brown's statement that the mean of all type A KMB ages ${ }^{2}$ is $3.12 \mathrm{Myr}$ ignores our distinction between types A-1 (more altered) and A-2 (less altered), with mean ages of $2.94+0.12 \mathrm{Myr}$ and $3.33+0.06 \mathrm{Myr}$, respectively. This evidently resulted from his not realizing that KM-1-74 (lab) and KM-2-74 (lab) were re-labelled from $\mathrm{KM}-2-74$ and $\mathrm{KM}$ 1-74 of ref. 3, when we discovered that the latter had been accidentally interchanged after grinding ${ }^{4}$. Brown's correlation places KMB in the Mammoth Event (3.15-3.05 Myr); if this is true, then not only is the unique type B too old, but so is the common A-2 variety. Our oversight in not including the older age measurements obtained for the type A-1 sample in the density fractionation experiment ${ }^{2}$ does blur the age distinction between types A-1 and A-2 somewhat (F. H. Brown, personal communication).

By this reasoning it becomes fortuitous that the most altered petrographic type yields the best $K / F \cdot r$ age, while the progressively less a tered types give ages too old because of extraneous ${ }^{40} \mathrm{Ar}^{*}$. Just considering the internal systematics of the KMB data and the lack of geological evidence for extraneous ${ }^{40} \mathrm{Ar}^{*}$ leads to the conclusion that the 